the bank below the pier, thus in some cases making matters worse. The only place I know of where a knowledge of the bad effects of eddies on river banks has been put in practice is in the river Adda, which drains Lake Como, Italy. There the irregularities of the banks seem to have been smoothed to some extent, and then simply paved with small cobble stones a few inches in diameter. Over this the water flows without eddies, and the banks, so far as one could see, gave little trouble, though one would imagine that if a break in this rather weak surface took place destruction might be rapid.

Ardenlea, Falkirk, December 3 .

\section{May Gorsedds.}

IN my communication to NATURe, May 2 (vol. Ixxvi. p. 9), I stated that there was another plan of a Gorsedd among the Iolo MSS. at Llanover. The important difference between it and the plan published in that number is the omission of the solstitial stones. It is a MayNovember Gorsedd pure and simple, based on the equinox, and for that reason very interesting. Both plans are truer to ancient tradition than the present plan favoured by the bards. The present orientation is exclusively solstitial, against the best traditions in point. In the older plans the May-year is given the preeminence in one, and is the only year given in the other. In both the older plans the circle consists of nineteen stones, leaving open a splayed avenue on the east, the breadth of which corresponds to the sun's course from August to November and from February to May. Though the present plan of a circle of twelve stones at equal distance from each other is antiquarianly sound, one may regard the older plans as still sounder. I have elsewhere shown that the exclusively solstitial arrangement of the stones in the present plan is about the only point in connection with the bardic Gorsedd of doubtful antiquity.

The accompanying tracing (Fig. I), for which I am indebted to Mr. $T$. H. Thomas, shows how the original plan was rather carelessly drawn, just the kind of diagram which an old bard would draw to accompany a written description, as in this case, for the benefit probably of an engraver.

In the formal and authentic bardic records very little is said about the significance of the various features of the Gorsedd circle. There is no dabbling in archæology.

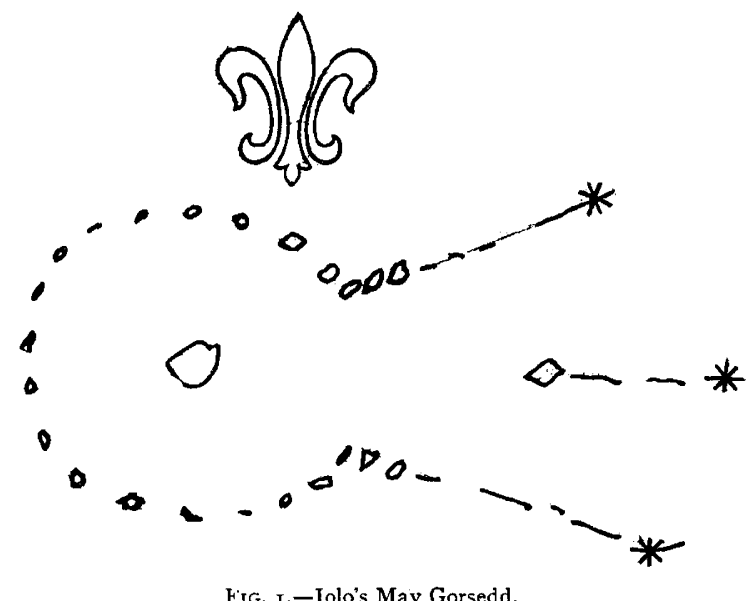

It is enough for the bard to be able to say that everything he records is sanctioned by immemorial custom.

In the second quarter of the last century a bard arose who claimed also to be a chief bard or archdruid, having the bardic name "Myvyr Morgannwg." $\mathrm{He}$ attempted a scientific and philosophical interpretation of the Gorsedd. $\mathrm{He}$ insisted upon the absolute identity of the bardic institution with the circles of the Stone age. He made several successful hits at the truth about the Gorsedd, but wild speculations and irrelevant matter have made his various writings hardly readable.

No. I989, VOL. 77]
The accompanying diagram (Fig. 2) represents Myvyr's idea of the "most essential elements of the Gorsedd," and is reproduced from one of his controversial pamphlets. It describes a May-November Gorsedd, but with the solstitial signs, except that Virgo is fixed at the equinox. The diagram is true to the best type, but the interpretation is a misfit. It is a forcible illustration of the disturbing effect of a solstitial cult upon sound May-year tradition.

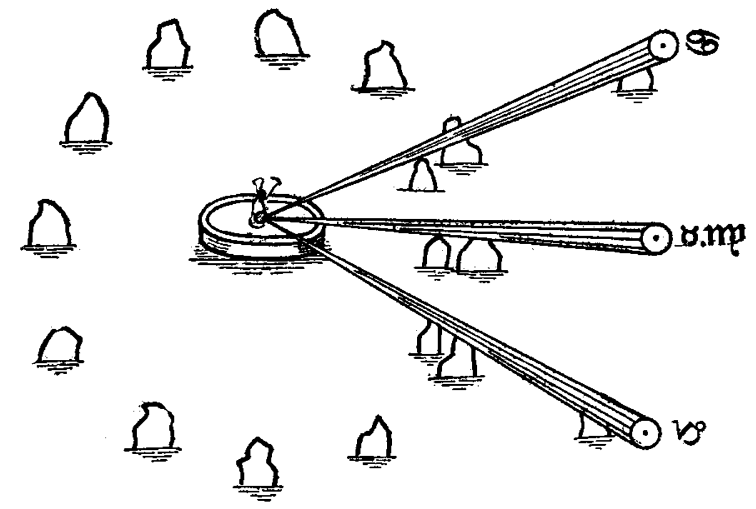

Fig. 2.-Myvyr's May Gorsedd.

Myvyr has also brought his fancy to play on the central stone. A mannikin, holding up something like a bow and arrow, occupies the place of the chief bard, and the three rays look very much like three clubs. Myvyr has nothing to say about the only valuable feature of his Gorsedd, namely, the May-November alignments.

JohN GRIFFITH.

\section{A FISHING TRIP TO THE GULF OF MEXICO. ${ }^{1}$}

M R. AFLALO describes a journey to Florida viá $\mathrm{M}$ New York, a fortnight's tarpon and other fishing in Florida, and the journey home by way of sundry Central American and West Indian ports. The account given by the author of his outward journey differs in no material respect from numerous extant accounts of similar journeys, but is somewhat marred by a style rather reminiscent of that of the traveller who has perforce to provide his daily or weekly quota of copy for some periodical publication. Such sentences as "In the middle of the ship soft-voiced stewardesses gently raise thick curtains and say that dinner will be up in a minute. It usually is. Fore and aft there is neither curtain nor stewardess, but one sufferer leans across a neighbour of a different race and obeys the irresistible. Everything comes up, even the moon at last . . " are hardly worthy of a serious volume. There are, however, interesting if slight allusions to and photographs of the Bronx Park Zoological Gardens and New York Aquarium, and a good account of a typical American health and pleasure resort in North Carolina.

Coming as it does from so well-known an authority on sea-fishing as $\mathrm{Mr}$. Aflalo, the second section of the book is naturally by far the most interesting. The account given of tarpon fishing as pursued at Boca Grande is both full and lucid; a sufficiency of detail as to gear, methods of using it, and expenses is given without any meedless discursiveness or undue brevity. The whole circumstances of the sport are brought clearly before the reader; the string of boats, each with its armchair fixed athwartships for the angler, towed out to the fishing grounds by a launch in the morning; the fish gaffed long ere they are played to a finish in the fisherman's eagerness to get back to the grounds and kill a larger one; the annoyance resulting 1 "Sunshine and Sport in Florida and the West Indie." By F. G. Aflalo. Pp. xv +272 . (London: T. Werner Lau ie, n.d.). 
from hooking anything that is not a tarpon, and the homeward journey to the scales, where the fish are weighed and wasted, for, unlike its Asiatic congener, the tarpon is never used for food. Notwithstanding that we are told that luck and brute force count for far more than skill in tarpon fishing, it is curious what a fascination the sport has for its votaries; there is something beyond the surroundings and beyond the huge size and strength of the fish itself (for these latter, great as they are, become insignificant when compared with the power and bulk of the great serranids and sharks, which are but "vermin", to the tarpon fisher) that lends a glamour to the sport. It is curious to find the same author between the same covers dazzled by this glamour, and yet talking of " the semi-artificial sport of deer ' forests' (sic)," setting the armchair and brute force of the tarpon fisher higher than the rough hillsides, patience, and skill of the decr-stalker.

wish to visit the West Indies, and holds out some hope that Jamaica may hereafter find prosperity as a resort for British tourists.

It only remains to add that the printing and appearance of the book are good, and that an excellent index is provided. The book is well illustrated from photographs, and we are enabled by the kindness of the publisher to reproduce an illustration of the New York Aquarium, showing how an old fort has been adapted for this use; the open tanks built into the floor for the reception of large fishes are well shown in the picture, and present a feature which would seem worthy of imitation on this side of the Atlantic.

L. W. B.

\section{GREEK ARCHAEOLOGY.}

THE articles in the latest volume of the "Annual of the British School at Athens" which are of most importance are those by Mr. R. C. Bosanquet, the late director of the School, and his assistants, which describe their excavations in the temple and precinct of the goddess Artemis Orthia at Sparta. Thus, for the first time for some years, the main interest of the School's work is transferred from things " $\mathrm{M} \mathrm{y} \mathrm{c} \mathrm{e-}$ næan " or " $\mathrm{Mi}$ noan" to antiquities of the "c 1 as s i c a 1 " period. The excavations of the School at Palaíkastro, in Crete, which have produced so many interesting monuments of the older civilisation of Greece, have been brought to an end (Mr. Dawkins describes the last flicker of this work last year in the present volume), and a

Transformation of an old fort into the New York Aquarium. From "Sunshine and Sport in Florida and the West Indies.

A chapter in this otherwise interesting section of the book devoted to speculations upon the early lifehistory of the tarpon is marred by the author's preliminary assumption that Megalops is a "herring," an assumption the more surprising when it appears from other passages in the book that he is well acquainted with one, if not both, of its real allies, Elops and Albula. Perhaps, however, in the case of one who does not claim to write as a scientific ichthyologist, such an assumption may be pardoned, as may his want of knowledge of Gill's paper (Smithsonian Miscellaneous Collections, I005) dealing with the early histories of Megalops and its allies, and epitomising our existing knowledge of the singular metamorphosis passed through by the young of these fishes.

The concluding section of the book contains some useful suggestions for the sea-fisherman who may NO. I 989 , VOL. 77$]$ new scene of labour, amid totally different surroundings, and productive of totally different results, has been wisely chosen. This is as it should be. Eventually the present phase of the school's work will also exhaust itself, and then, all in good time, the attention of the school will no doubt again be turned towards Mycenæan matters. Dr. Arthur Evans will by that time have published his great book on Knossos, the Italian results will also be published, and we can start afresh with renewed interest and increased knowledge, derived from the complete study of the results of the previous period of excavation. Then the school will, it is to be hoped, complete the great

"The Annual of the British Srhool at Athens," xii. Pp. $x i+523 ; x z$ plates ; and illustrations in text. (London: Macmillan and Co., Ltd., 1905-6.)
Price 25s. net. 